\title{
Review on Enset (Enseteventr icosum) Value Chain in Ethiopia
}

\author{
Lisanu Damene Daracho \\ Jimma University P.O.Box 307 Jimma Ethiopia
}

\begin{abstract}
Enset is one of the main staple or co-staple crop produced and marketed in most of SNNPR and Oromia Regions of Ethiopia. The objectives this review paper is:- to assess the production and marketing of enset in Ethiopia, to identifying major challenges and opportunities of enset production and marketing in Ethiopia and to reviewing the enset value chain actors with their specific roles. In line with this, the main constraints of Enset production are mentioned as, pest and disease spatially Enset Bacterial Wilt caused by Xanthomonas musacearum and technology limitation, limited access to improved disease resistant varieties, and limited capacity in research and development. The main constraints of Enset Product marketing are low price for the products, poor product handling and packaging, imperfect pricing system and lack of transparency in market information system mainly in the rural to town and city market. The main value chain actors involved along Enset product value chain are producers, local collectors, wholesalers, retailers, hotels Consumers.
\end{abstract}

Keywords: Challenges, Enset, Opportunities, Value chain actors

DOI: $10.7176 / \mathrm{JRDM} / 65-03$

Publication date:May $31^{\text {st }} 2020$

\section{Introduction}

\subsection{Background of the review}

Agriculture is the backbone of the Ethiopian economy and it contributes roughly more than half of the rural population directly engaged in the sector as an economic activity. In Ethiopia, agriculture is the most essential sector and it accounts for $43 \%$ of GDP, $90 \%$ of export commodity, $70 \%$ of industrial raw materials and $85 \%$ of employment covered by agriculture. According to EES (2016), Agriculture's contribution to GDP high, although showing slight decline over the years has remained very high. In most of developing country almost all export commodity are agricultural product and product made from it.

Ethiopia is mainly an agrarian country of the world. Smallholder and family farming agriculture remain to be the key and leading sector in overall economic development of many developing countries in the world. In addition to producing staple crops for domestic markets; smallholder farmers produce large shares of traditional exports in these countries. This shows how the economy of many developing countries still reliant on smallholder-based agriculture and smallholder farming accounts for about 75 percent of agricultural production (Salami et al., 2010).

Most of the time in developing country smallholder and family level farming face a number of the problems like adverse climatic conditions, lack of appropriate land use system resulting in soil and other natural resources degradation, limited use of improved agricultural technologies, the predominance of subsistence agriculture and lack and/or absence of business oriented agricultural production system (Bezabih, 2010).

Enset occurs in wild forms in East, Central and South Africa. Even though the banana fruit is known worldwide Enset (Enseteventricosum) is only cultivated as a crop in Ethiopia for long time ago. Outside Ethiopia country, the use of Enset is reported from Vietnam, where it provided an emergency food during the Second World War. In parts of north and central Vietnam, the growing point was used as a vegetable crop (Tsegaye and Westphal, 2002).

Enset crop grows at a wide range of altitudes however it grows luxuriously at elevation between 2000 and 2750 m.a.s.l, under rain fed conditions and the crop have high drought resistance character (Taye et al., 1984). The crop is grown in many regions but the dwellers of the central and southwestern parts of Ethiopia are the only people who use enset as a staple and co-staple crop (Stanley, 1966). Most part producing area this crop grown for staple food. In south region Dawro, Gurage, Silte, Hadya, Kembata, Kaffa, Wolaita and half part of Shekka, Debub omo, Gamo and Gofa zone and totally part of Konta specially woreda human use this crop throughout the year for home consumption and income gain.

Even though there is a huge demand and potential of agro-ecology for enset production in Ethiopia parts of production area, the farmers are still facing different problems related to, input supply, modern enset farming system, market information for selling enset product in good price and accesses to market and more ever the product is not known in all parts of the country. Therefore, this review is written by studies of enset product value chain analysis indifferent part of Ethiopia. This review paper have one general objective to overview enset value chain in Ethiopia and three specific objectives i) To reviewing the enset value addition and value chain actors with their performance in Ethiopia. ii) To identifying major constraints and opportunities of enset production and marketing in Ethiopia and to assessing the production and marketing of sesame in Ethiopia. 


\section{Enset Value Chain in Ethiopia}

\subsection{Overview of Enset production and value chain in Ethiopia}

Enset also known as "false banana" due to its striking resemblance to the banana plant, Enset (Ensete Scitamineae) is a traditional staple crop in many parts of densely populated south and south-western Ethiopia. Enset has been grown in Ethiopia for more than 10,000 years. Indigenous hunter/gatherers of southern Ethiopia are thought to have been the first to cultivate Enset, and later introduced it to the Cushitic-speaking people of the northern highlands, only for it to be replaced by cereal based crops due to the migration of the Semitic people (Tsegaye, and Struik, 2002).

Enset (Ensete ventricosum) is a drought tolerant crop, traditionally grown in Ethiopia. It has many usages: food, fodder, fibres and traditional medicine. Being perennial, enset improves local climate and soil conditions. It could contribute to improved food security in several drought-prone parts of the world. The aims of enset crop production were to reveal the amino acids of Enset corm, which can be cooked as a root crop, and to increase the general knowledge regarding chemical composition and energy values of different enset fractions. Water content was high, 85 to $90 \%$, which is beneficial when used as fodder during dry periods (Demeke, 2011).

Enset corm contained 17 of 20 amino acids and had similar or higher concentration than potato of 12 of these. Leaves had 13\% protein, among the highest available in Ethiopia, 20\% crude fibre and 10\% sugar; a good fodder and suitable for ensilage. The pseudo stem, the main food source, was rich in soluble carbohydrates $(80 \%)$ and starch $(65 \%)$, but had low protein content (4\%). An enset based diet should be supplemented with protein and complementary amino acids; for example from beans, which are suitable to intercrop with enset (Olanlg et al., 2014).

Acording to Areka agricultural research enset (Enseteventricosum is a herbaceous monocot, large bananalike plant that grows $4-8 \mathrm{~m}$ (some time $7-11 \mathrm{~m}$ ) in height. Enset traditionally ranked first in importance as cultivated staple food crop in The high lands of central, south and south western Ethiopia. The main food product from it is obtained by fermenting the mixture of the scraped pulp of the pseudo stem, pulverized corm and stalks of in florescence and is locally known as 'kocho'. Most of the time the area where enset is used as staple food are characterized by high density of human population, which cannot be supported with any other type of land use (Olango et al., 2014).

Enset yield is relatively high compared with yields of other food crops. Brandt et al., (1997) suggested that the huge volume of harvested yield from on Enset plant and from an area, particularly compared to cereals, contribute perception among both farmers and scientists that the yield of Enset is tremendous. There are many enset clones in different agro ecologies. Farmers classify their landraces and give them different names based on several attributes that distinguish the landraces from one another. The names given by farmers to the different enset clones separate the landraces linguistically, phenotypically and in terms of their utilization value (Tsegaye, 2000). The Enset products are used for human and animal feed in different form. In southern region in Dawro and Konta specialy woreda Product of Enset used in the form of Kocho Kitsa, Genffo" Shendera" Bacirra and other forms of food for humans. The products of Enset in this area used as holiday food like Baccira and cultural food for mothers during new baby born time (Alemayehu, 2017).

In Ethiopia 7 to 10 million people cultivate the crop as a staple food or as a co-staple with cereals and root and tuber crops (Tsegaye and Struik, 2002). Ethiopia is a country, which has high production of enset plantation than all African countries (Chiche, 1995). Enset (Enseteventricosum (Welw.) Cheesman) which contain more than 100 varieties is a perennial herbaceous monocot banana-like large (grow 4 to $8 \mathrm{~m}$ which even sometimes reach up to $11 \mathrm{~m}$ in height) plant belonging to the family Musaceae, genus of banana of which none is found cultivated in other part of the World. Enset is native to Ethiopia and the greater concentration of this species is found in the South and Southwest part of the country and the area coverage under this crop is rapidly increases time to time.

Enset cultivation occupies a central position in the agricultural systems of the Ethiopian high land area of south and oromia region and every farming household cultivates enset in its home garden. In most part of enset producing area are maintained in home garden ring in poly-varietal perennial plantations without any crop rotations and land fallowing. Sometimes, farmers maintain enset landraces intercropped with perennial tree crops, such as coffee (Coffea arabica L.), avocado (Perseaamericana Mill.), guava (Psidiumguajava L.), and annual and biennial crops, such as maize (Zea mays L.), Ethiopian kale (Brassica carinata A. Braun) and yam (Dioscorea spp.). Enset is one of the most widely cultivated crop in Wolaita, Dawro zone and Konta specially woreda primarily in midland and highland areas. Although it covers a relatively smaller area per unit of production compared to cereals and pulses. When asked about the importance of enset, producer indicated enset for a multipurpose crop available all year round and that needs only household produced inputs for its production. The producing communities and Department of Agricultural and Rural Development define enset as the most important crop for livelihoods and food security in the producing area (Habte-Wold et al., 1996).

The 'corm' or juncture of root and stem of an old plant is cut into pieces and planted in the nursery, producing 50 to 350 new shoots. These are broken off and transplanted in rows using one square meter per plant for the next two years. New enset plants are transplanted at least twice during the growth period in order to save space. After 
two years the plants are dug up roots and leaves trimmed and transplanted into 2.25 meter squares for the $3^{\text {rd }}$ through $5^{\text {th }}$ years. The final transplanting is to 7-9 meter squares again disturbing the roots and reducing the leaf area to minimize wilting. They remain in the squares for the $6^{\text {th }}$ year until harvest which may be in the $7^{\text {th }}$ to $9^{\text {th }}$ years depending upon the needs of the family (Tsegaye, 2000).

Throughout this time the soil is tilled for weeding and the incorporation of manure. The importance attached to the growing of enset is seen by the clean weeding or mulching of the plantation. Intercropping the bare areas is not practiced but plantings may occur where individual plants are harvested or have died from disease or transplanting shock. Other than the nursery for starting plants, all the manure of the farm is incorporated into the enset plantation. Soils in this area are inherently acidic, with heavy clays that retain high levels of organic matter when applying manure, and give good nitrogen fertility that would benefit further from liming and phosphorus (McCabe and Lee, 1996).

Suckers are transplanted using a hand hoe, usually to an area that has been well prepared with added animal manure. Transplanting is usually done in the dry season due to the heavy nature of the soil which would turn into hard pieces if compacted under wet conditions. Nevertheless, considerable growing time is lost and the plants suffer wilting damage. Different research indicated that averaged over four different varieties, the pseudostem length was 0.7 and 1.4 meters shorter with 1 and 2 transplanting respectively as compared to direct planting of shoots. Research into the size of the hole for transplanting and the amount of root/leaf trimming was aimed at minimizing these stresses. Moist loose soil around the base and minimal leaf transpiration were found to be advantageous to rooting establishment of transplants (Alemu and Sandford, 1991).

The crop is grown in many regions but the dwellers of the central and southwestern parts of Ethiopia are the only people who use Enset as a staple and co-staple crop (Stanley, 1966). These regions are among the most densely populated in the whole of Ethiopia and are inhabited by more than 11 ethnic groups, which show great variation in culture and agricultural practices (Tsegaye and Struik, 2002). The Ethiopian Central Statistical Agency (2011) indicates that 3,020.143 km2 of land is covered by Enset crop and about 6.9 million quintals of Enset yields were produced in 2010/11 production season.

\subsection{Challenges of Enset Crop Production and Marketing \\ 2.2.1. Challenges of Enset Crop Production}

The major challenges in enset production in Ethiopia that recurrent lack of enough research in enset Production and marketing, drought, disease, lack of improved clones in terms of yield, lack of disease resistant variety, shortage of training to producers how to cultivate, lack drought tolerance variety; lack of improved processing and storage technologies, improper or traditional agronomic practice, long time maturity and food shortage/starvation. Poor agronomic and traditional cultural practice such as frequency of transplanting, spacing, fertilization, pruning and so on are done blanketly that significantly affects both production and productivity of enset in the area. Once again frequent transplanting and cultivation also has direct relation to crop maturity, productivity and efficient utilization of labour, land and time as well. More over the farmers in the area do not have any know how about the amount, type and method of fertilizer application that significantly affects its production since the crop by nature highly respond to applied fertilizers be it organic or inorganic (Abrham et al., 2012).

There are a number of factors influencing enset popularity among farmers in Ethiopia. These factors are geared toward independent household survival in farming systems that have been fraught with pests, surprised by erratic rainfall and scourged by government urbanization. Enset cultivation has been undeveloped by independent farmer investigation and enset crop have been utilized to provide consistent food availability to smooth over the rough times of household food security. Absence of commercial farming system, less attention to crop by government, lack of wide research on crop and reliable documents are also main problems to the sector. Self Help Development Agency is an Irish-based development agency, involved in the implementation of long-term development projects in Africa. The agency has field offices in Ethiopia, Malawi, Eritrea, Kenya and Uganda (Demeke, 2011).

There have been obstacles facing those engaged in promoting the propagation of enset, the most fundamental being it takes three to five years for the plant to achieve maturity. While a five year old plant can yield $40 \mathrm{~kg}$ of food, farmers who harvest after a single year can expect a yield of just one kg from the pseudo stem - the bowl of the tree which is processed for food. Although it is estimated that there are currently upwards of 10 million people in southern Ethiopia consuming enset in their diet, there are historic and cultural reasons why others in the country do not. During the reign of Emperor Haile Selassie (1930-1975), the Ethiopian Ministry of Agriculture launched major initiatives to increase food production. The emperor gave strict instructions to focus on cereal crops and income-generating crops, such as coffee, while the enset plant was ignored. The situation for enset did not improve under the subsequent Socialist Derg regime (1975-1991), whose research projects had insufficient funds, and did not examine the potential of a crop (FDRE, 2008).

There have been cultural barriers to the popularity of enset too. Many urban Ethiopians regard a crop, which is used by southerners for everything from food, bedding and clothing to house building and fodder, as little more 
than a peasant food (FAO, 2012).

A number of factors have acted to change this perception, however, and market forces - which have seen the price of enset remain stable while cereal grain prices have climbed -has been a significant one. Not to be underestimated, either, has been the realization that famine can, and has been, averted at times of drought, in areas where the enset crop is being grown and processed by rural communities (IFAD, 2012). Diseases such as bacterial wilt (Xanthomonas, campestris, pv, Musacearum, EXW), pests (Enset root mealy bugs, leaf hopper, mole rat and porcupine) and soil nutrient depletion are some of the production constraints encountered in the s Ethiopian Highlands. It is reported that up to $80 \%$ of Enset farms are currently infected by EXW.

\subsubsection{Challenges to enset crop marketing}

The governmental touting of a free-market economy, traders have developed Kocho collection and marketing systems. The divergent goals and production methods are developing among households and in certain geographic areas where commercial production is diverging from domestic production. It is commonly known that the highest amount of Kocho production per Oplant occurs just prior to flowering (though not necessarily the most per unit area). Current commercial production centers include Gedio zone, Dawro zone, adjacent Borena weredas, Gurage zone with adjacent Shewa weredas of Welisso, Wenchi and Tikur Inchina. In these areas growers allow plants to reach a larger size and may include more plant material (outer leaf sheaths, longer pseudostems and more fiber) into the Kocho and are less likely to segregate Kocho qualities at the time of fermentation. If this practice is or becomes extensive, determination of a separate model with more extensive data from plants yielding 70 to 150 $\mathrm{kg} / \mathrm{plant}$ should be formulated for commercial producers (Abebe and PAUL, 2015).

A quick market survey in the Addis Ababa-Merkato was conducted by the authors. About 120 women reported selling 2 'Jump' of Bulla and 4 of Kocho each per week. They also said that people commonly buy an entire Jump of Kocho for a family holiday. This amounts to 25,000 Jumps of Kocho (2,000 mt) and 12,500 Jumps of Bulla per year. There are also smaller satellite markets selling Enset products in Addia Ababa. The market and marketing challenge in most part of Ethiopia Kocho marketing are lack of composed market information, price of the kocho and other products are low, most of the product sold in the farm, there no demand of kocho and its products in most part of the country, Most part of our country do not have knowledge how to consume kocho and its product, have high water contents make it not easily to market and lack of enough transport access to collect product to the market (Anbes et al.,2015).

\subsubsection{Opportunities for Enset production and marketing in Ethiopia}

According to different research conducted in Oromyia Region and SNNPR of Ethiopia the area also have favorable environmental conditions for Enset production and marketing. It has an altitude ranging between 2200 to 3023 m.a.s.l. The annual temperature ranged between $6^{\circ} \mathrm{C}$ and $24^{\circ} \mathrm{C}$, and annual rainfall between $100 \mathrm{~mm}-1800 \mathrm{~mm}$ which is appropriate for enset production. Ethiopia economies are increasingly confronted with changing food and commodity markets, due to globalization, economic liberalization and urbanization (Heike, 2005). As a result, consumer preferences change.

This poses new opportunities but also challenges to small-scale producers, traders and Processors along agricultural value chains. To address this situation, development agencies, donors and NGOs are placing more emphasis on enabling Farmers to increase their level of competitiveness, to produce for an identified market, rather than trying to sell what they have already produced and also seeking new market opportunities that offer higher levels of income. Such goals can be achieved through better economic coordination and institutional linkages. Farmer organizations can play a key role of organizing economic activities beyond local boundaries. They can build up relationships with various chain actors and securing commitments from various actors to cooperate on mutually beneficial actions and investments and thus create value chains (Bezabih, 2010).

The marketing system of ensent product in Oromia and South region were interconnected characteristics, such as the number and relative strength of buyers and sellers and degree of collusion among them, level and forms of competition, extent of product differentiation, and ease of entry into and exit from the market. There is perfect competition in market while there are many buyers and sellers are found in enset product market because of near popularities of the crop type (Anbes et al., 2015).

The enset producing areas have high consumption of enset products. There was also growing demand for food self-sufficiency and food security. Enset plant is able to withstand or quickly recover from difficult conditions (drought and climate changes) and can be stored for long periods. The high yield from small plot is one of the best opportunities for the producer farmers and for those who has small area of land. Ghimiray et al. (2007), confirm that higher yield potential is considered as an important factor particularly for farmers' innovation not only because it provides food security at household level but also because surplus production can be sold to generate cash for other expenditure.

The farmer produce enset nearest to the town and cities was one of the most important opportunities for the enset producer farmer to sell their products (Bulla, Kocho, Amicho, Fiber and fresh enset leaf) as well. It is also the most important opportunity for the traders retailer and wholesaler) to easily buy the enset product from the producing area without much transportation cost. Availability of infrastructure development in Ethiopia and this 
has created an opportunity to transport and supply enset products to the market. Research conducted by (Anbes et $a l, 2015)$ in Ethiopia enset producing area about $86.5 \%$ of the respondents had access to market in their locality, about $43.6 \%$ of the respondent farmers sold enset products and about $94.4 \%$ of the respondent farmers greenest product as 'Etma', 'Godeta' and 'Gola'. About $98.8 \%$ of producing area farmers confirmed that higher product quality fetches higher price and received quality premium (95.7\%). More than half of the respondent farmers could not get market information. First, the grain markets have experienced a considerable increase in the price of cereals, while the price of kocho has remained relatively constant.

Urbanites shopping in the markets of Addis Ababa, especially those from enset growing regions, are choosing to purchase enset products both for taste and to make their limited incomes go further. Enset products kocho, bula, and enset by product fibres and enset leaves are traded within and outside the district and zone market increases the market value. These products are traded mainly to nearest zonal, regional and national market. In south region enset products are mainly marketed in wolaita, hawasa, hosaina, wolkite town and Adis Abeba city and in Oromia region in Guder town, Jimma town, Illubabur, Ambo town and Addis Ababa city (Anbes et al., 2015).

\subsection{Common use value of enset crop or enset value addition}

The majority of enset production is confined to Sidama, Dawro, Konta, Gurage, Shoa, Keffa, Gamo, Goffa and Illubabor administrative regions (Addis, 2005). The major foods obtained from enset are 'Ettima', kocho, Bulla and Amicho. Some researchers are also conducted research on using ensetfor industrial starch manufacturing .but, this research focuses on processing kocho and bulla in industry level to solve the problems existed on processing aspects by designing specially fermented, squeezer and dryer. About $94.4 \%$ of the different are Enset producer's farmers' grade Enset product as 'Etma', 'godeta' and 'gola' (Anbes et al., 2015). Even though it is grown in many administrative regions, the dwellers of the central and southwestern parts of Ethiopia are the only people that use enset as a staple and co-staple crop (Simmonds, 1958).

$\checkmark$ Etma: First grade enset product, also known as bulla. This product is most sweet product of Enset Product and it has high market value.

$\checkmark$ Godeta: Second grade Enset product prepared from chopped and fermented amicho, also known as worqeGola:

$\checkmark \quad$ Third grade Enset product made from decorticated pseudo stem

$\checkmark$ Fiber (Gola"): Non edible enset product used to make various house utilities including rope Kocho, bulla and fiber are the main products which are marketable in the country in general and southern region in particular Dawro, Gamo, Gofa, Hadya, Gurage, Kaffa zones and konta specialy woreda and Oromia region particulary in jimma zone, weliso, Borena and other parts.

$\checkmark$ Kocho, bulla and fiber take about $40.46 \%, 24.86 \%$ and $33.53 \%$ of the market share, respectively in most part of Ethiopia Enset producing area.

$\checkmark$ Amicho takes negligible share of the Enset market.

From the above Enset product different value added food and fiber products are produced. The most common food from Enset product are:-

$\checkmark$ Kocho kitta which can be baked to thin bread, provides a good source for Ca and Fe.

$\checkmark$ 'Genffo'

$\checkmark$ 'Shendera'

$\checkmark \quad$ 'Baccira' and rofe from fiber or (Gola) used to tie animals in feeding place.

Leaves of Enset and and other byproduct that are not used by humans are used for Bedding of economical poor humans and animal feed.

\subsection{The major actors in Enset value chain of Ethiopia}

Value chain analysis is important in determining the relationships and linkages between different value chain actors and a range of market actors in between (Wenz and Bokelmann, 2011). A Value chain of Enset is a business structure of interdependent organizations that reach from the point of product origin to the consumer with the purpose of moving products to their final consumption destination. The Enset value chain in Ethiopia is poorly organized, although it is currently under reform since the introduction of the new market auction system. There are various actors in Enset value chain. These include producers, local collectors (collecting middle men), Wholesalers, retailers, hotels and individual local consumers. Value chain mapping and actor identification were directed at the supply chains for enset and enset product. There are different actors are identified in enset value chain in this review.

A. Producers:-They are farmers who produce different product of Enset and manage farm level production process, determine quality of Enset product during variety selection and production process and provide different Enset product to local market. Major processing activities are done by producers. Processing is the act of converting enset into enset products such as Kocho, Bulla and Amicho. enset Processing is labor intensive, and is usually done by women using traditional tools, although men help with cutting 
and harvesting the mature plant. Processing Involves: Cutting and harvesting the mature plant, digging and lining a pit for fermenting the pulverized corm or root, scrapping (decorticating) the outer sheaths of the stem to remove edible parts.

B. Collector or local Traders:- They are traders collect different Enset product from farm and local market. They add value to the product by making easily usable and sell their product to district and zonal market by higher price than producers.

C. Wholesalers:- Wholesalers are mainly involved in buying Enset product from collectors and producers in larger volume and supplied them to retailers, hotels and final consumers. They also stored the product for short time. Wholesalers were the main buyers of Enset products in the most part of Enset producing area. They have better storage, transport and communication access than other traders.

D. Retailers:- are another key actors in Enset product value chain in Ethiopia. They are the last link in the value chain connecting traders with the consumers. In most Enset producing area, retailers mostly bought from wholesalers and local collectors and sold to consumers. Sometimes retailers directly bought from the producers also. Consumers usually buy the product from retailers as retailers offer according to the requirement and purchasing power of the buyers. It was observed that during the market survey retailers sold kocho, bulla, enset leaf and enset fiber.

E. Hotels:- most part of enset producing part of Ethiopia particularly in southern part like Wolaita, Dawro, Gurage, Hadya, kembata zones and Konta specially woreda 'Koch Kitta' are used by other food like meat and meat product, milk and milk product and with another traditionally and modern foods.

F. Consumers:- are final chain actors those purchasing the products for consumption. Enset Product consumers are of two types; rural and urban consumers. The former include producer farmers who consume themselves and urban consumers are those who live in the district town and zone town. Urban consumers purchased enset product directly from producers, wholesalers, and retailers But rural consumers most the time purchased from farmers directly from farm and local markets.

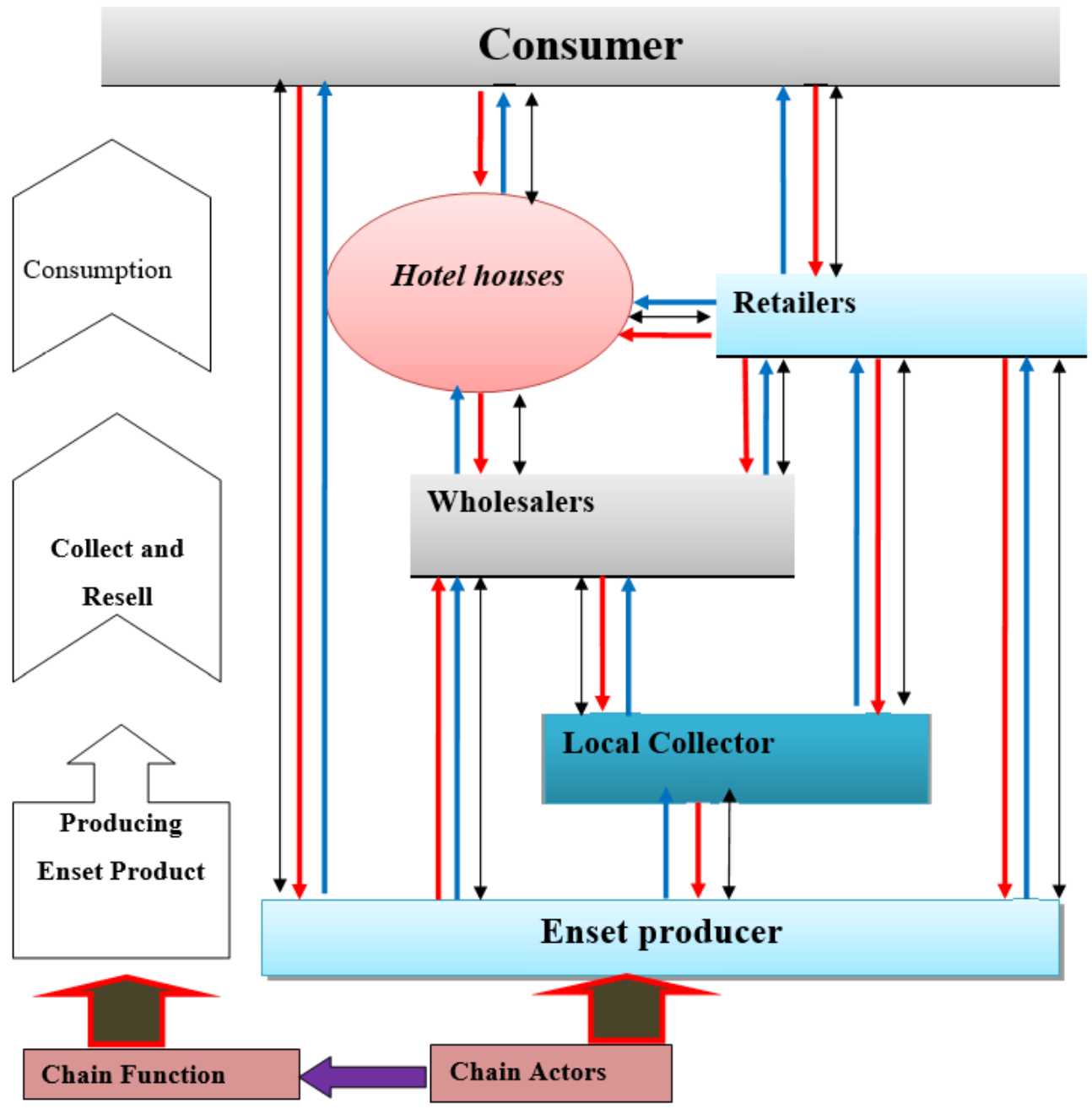

Figure 1: Enset value chain map 


\section{Conclusion}

From agricultural sector of the Ethiopia Enset ventricosum is the edible species of the separate genus of the banana family, thus named 'false banana' but its fruit is not edible. Variation within the species to altitude, soil and climate has allowed widespread cultivation in the mid- to highlands of the Southern Peoples Nations Natinalities Regional State (SPNNRS) including Dawro, Gurage, Hadya, Wolaita, Gamo, Gofa, Kmbata and Konta and western Oromia including West Shewa, Jima, Ilubabor and Welega. Three Enset derived foods are popular but the most common is Kocho, Bulla and Etima are well known.

Drought, disease, lack of improved clones in terms of yield, lack of disease resistant variety, shortage of training to producers how to cultivate, lack drought tolerance variety; lack of improved processing and storage technologies, improper or traditional agronomic practice, long time maturity and food shortage/starvation are challenges that hinder enset production and lack of composed market information, price of the kocho and other products are low, most of the product sold in the farm, there no demand of kocho and its products in most part of the country are marketing challenge of enset crop.

Ethiopia has wide range of agro ecology, increasingly food demand, due to globalization, economic liberalization and urbanization, interconnected characteristics, such as the number and relative strength of buyers and sellers and degree of collusion among them, level and forms of competition, extent of product differentiation, and ease of entry into and exit from the market are production and marketing opportunities.

Enset is staple and co-staple food in most part of South and Oromia region. The major foods obtained from enset for human consumption are 'Ettima', kocho, Bulla and Amicho. Non edible product from enset crops are fiber, leaf for bedding in rural society.

There are many actors involved in enset value in Ethiopia chain analysis, from input supply to the consumers playing different roles. They were: input suppliers, producers, collectors, wholesalers, retailers, hotels and consumers. But most part of Ethiopia enset producing area there is no well known enset input supplier. Enset products produced in the in different area passes through several intermediaries, like local collectors, wholesalers and retailers, before reaching the consumers. The intermediate buyers purchased the enset products from the farmers at a lower price and they sold to the end user at a higher price. The linkage among value chain actors was to some extent weak and informal in type.

\section{References}

Abebe Uma and Paul, 2015: Enset value chain analysis. The case of Dire Enchini woreda, Oromia regional state, Ethiopia.

Abraham S., Yishak G. and Melese T., 2012: Diversity, Challenges and Potentials of Enset (Ensete Ventricosum) Production: In Case of Offa Woreda, Wolaita Zone, Southern Ethiopia.

Addis T (2005). Biology of Enset Root Mealybug (Cataenococcus Ensete) Williams and Matile-ferrero (Homoptera: Pseudococcidae) and Its Geographical Distribution in Southern Ethiopia. MSc. Thesis, Alemaya University, Alemaya (Ethiopia),pp1-96.

Alemayehu Asfaw, (2017). Enset Value Chain, The Case of Dawuro Zone, Southern Nations Nationalities and Peoples Regional State, Ethiopia

Alemu k. Sand ford S. (1991), Enset in North Omo Region, Farmers' Research Project, Technical Pamphlet No. 1, Farm Africa, Addis Ababa, Ethiopia.

Anbes, Tenaye and Endrias Geta 2015, analysis of vulnerability and determinants of enset production in wolaita, southern Ethiopia.

Bezabih Emana, 2010.Market assessment and value chain analysis in Benshangul Gumuz Regional State, Ethiopia. SID-Consult Support Integrated Development, Addis Ababa, Ethiopia.

Brandt SA, Spring A, Hiebsch C, McCabe JT, Tabogie E, Diro M, Wolde-Michael G, Yntiso G, Shiegeta M, Tesfaye S (1997). The "Tree Against Hunger": Enset- Based Agricultural Systems in Ethiopia. American Association for the Advancement of Science, Washington.

Ethiopian Central Stastistical Agency (ECSA) 2011. Enset sample survey results. The federal Republic of Ethiopia, Central Statistical Agencey.

Chiche Y., 1995. Assessment of Enset and root crops contribution to food supply in Ethiopia.

Demeke, A. B., Keil, A., \& Zeller, M. (2011).Using panel data to estimate the effect of rainfall, and vulnerability in rural Ethiopia.Climatic change, 108(1), 185-206.

Ethiopia Economic Snapshot H2, 2016. The Ethiopian Parliament approved the budget for the 2016/17 fiscal year (FY, July to June) in early July.

FAO, WFO \& IFAD (2012), The State Of Food In Security On The World 2012 Economic Growth In Necessary But Not Sufficient To The Accelerate Reduction Of Hunger And Malnutrition Rome.

Federal Democratic Republic of Ethiopia (FDRE). (2008). Summary and Statistical Report of the 2007 Population and Housing Census, Population Size by Age and sex. Addis Ababa, Ethiopia: Population Census Commission. 
Ghimiray M., Wangdi K., Chhetri B.G., Bockel L. and Punjabi M. 2007. “Rice Commodity Chain Analysis”, FAO, Rome

Habte-Wold, T., Sandford, S., and Kindness, H., 1996. The age and sex structure of enset plantations in north Omo.

Heike Hoeffler 2005, "Promoting the Kenyan Potato Value Chain: Can Contract Farming Help Build Trust and Reduce Transaction Risks?", Paper prepared

McCabe J.T., and Lee, S.A., 1996. The role of livestock in the enset cultivation system. Paper presented at the Annual Meetings of the American Anthropological Association, San Francisco.

Olango, T.M., Tesfaye, B., Catellani, M. and Pè, M.E. (2014). Indigenous knowledge, use and onfarm management of enset (Ensete ventricosum (Welw.) Cheesman) diversity in Wolaita, Southern Ethiopia. Journal of ethnobiology and ethnomedicine, vol. 10, no.1, pp 1-18. Available online at http://www.ethnobiomed.com/content/10/1/41

Salami, Adeleke; B. Kamara, Abdul; and Brixiova, Zuzana (2010), "Smallholder Agriculture in East Africa: Trends, Constraints and Opportunities", African Development Bank Group, Working Paper Series No. 105, April 2010.

Simmonds NW (1958). Ensete Cultivation in the Southern Highlands of Ethiopia: A review. Tropical Agriculture, 35:302-307.

Stanley S (1966). Enset in Ethiopia Economy. Ethiopia J. Geographica, 10: 30-37.

Taye B, Feleke A, Regassa B (1984): The Cultivation of the Genus Ensete in Ethiopia. Soil and Crop Sci. Soc. (Florida), 27:133-141.

Tsegaye, A., Negash, A., Van Treuren, R., Struik, P.C., 2002. Comparison of enset (Ensete ventricosum (Welw.) Cheesman) characterisation based on farmers' knowledge and on AFLPs for efective conservation and utilisation of genetic resourcesinEthiopia.SubmittedtoCropScience.

Tsegaye, A., 2000.Manual on enset production, protection and utilisation. Centre for Development Initiative (CDI), AddisAbaba,Ethiopia, 75pp.

Wenz, K. and Bokelmann, W. (2011). "Incorporating Value Chain Research and Problem-Based Learning into Horticulture and Agriculture Study Programs in Kenyan and Ethiopian Partner Universities", African Journal of Horticultural Science, vol. 4, no.1, pp 1-6. 